\title{
Identification and Analysis of Differentially Expressed Genes During Seed Development Using Suppression Subtractive Hybridization (SSH) in Phaseolus vulgaris
}

\author{
Ghassen Abid • Khaled Sassi • Yordan Muhovski • \\ Jean-Marie Jacquemin • Dominique Mingeot • \\ Neji Tarchoun • Jean-Pierre Baudoin
}

(C) Springer-Verlag 2011

\begin{abstract}
Interspecific hybridization in the genus Phaseolus, conducted to introgress desired traits into common bean (Phaseolus vulgaris L.), leads to the abortion of immature embryos, usually at early developmental stages. Little is known about the physiological responses of embryo dysfunction in $P$. vulgaris during the early stages of embryogenesis and the genes that are involved in these
\end{abstract}

\section{G. Abid $(\square)$}

Centre of Biotechnology of Borj Cedria, Laboratory

of Legumes, University of Carthage,

901,

2050 Hammam-Lif, Tunisia

e-mail: gha_abid@yahoo.fr

\section{K. Sassi}

National Agronomy Institute of Tunisia (INAT), Department of Agronomy and Plant Biotechnology, Laboratory of Agronomy, University of Carthage,

Avenue Charles Nicolle, 43,

1082 Tunis-Mahrajène, Tunisia

\section{Y. Muhovski $\cdot$ J.-M. Jacquemin $\cdot$ D. Mingeot}

Department of Life Sciences, Walloon Agricultural Research

Centre, Unit of Breeding and Biodiversity,

Chaussée de Charleroi, 234,

5030 Gembloux, Belgium

\section{N. Tarchoun}

Unit of Organic and Conventional Vegetable Production,

Agronomic High Institute of Chott Mariem, University of Sousse, 47 ,

4042 Sousse, Tunisia

\section{J.-P. Baudoin}

University of Liège-Gembloux Agro-Bio Tech. Unit of Tropical

Crop Husbandry and Horticulture, Gembloux Agricultural

University,

Passage des Déportés 2,

5030 Gembloux, Belgium responses. Identification of the genes involved in Phaseolus embryogenesis may provide information that will help to understand the molecular basis of Phaseolus embryo dysfunction. To investigate the genes expressed during Phaseolus seed development, we constructed a suppression subtractive hybridization (SSH) library using cDNA from abortive seed development as the driver and those from normal seed development as tester. The differentially expressed cDNA fragments were identified by differential screening. We identified 72 unique ESTs of which we selected 12 candidates on the basis of their redundancy. These candidates were subjected to a validation procedure based on the study of their expression level by real-time PCR. Sequence analysis revealed that most of the differentially expressed genes are related to metabolism and regulation such as protein synthesis. Some genes also encoded transcription factors. These genes showed high mRNA transcript levels in seed tissues and little or no expression in other tissues (root, stem, flower, leaf, and cotyledon). Seven genes were chosen and their expression profile during seed development in $P$. vulgaris was analyzed by real-time PCR using RNA preparations originating from different seed development stages. This study revealed hitherto unknown genes putatively involved in dicotyledonous embryogenesis, which serve as a starting point for understanding Phaseolus embryogenesis.

Keywords Phaseolus · Seed development · RT-PCR · SSH

$\begin{array}{ll}\text { Abbreviations } \\ \text { DAP } & \text { Days after pollination } \\ \text { EST } & \text { Expressed sequence tag } \\ \text { RT-PCR } & \text { Reverse transcription polymerase chain reaction } \\ \text { SSH } & \text { Suppression subtractive hybridization }\end{array}$




\section{Introduction}

Common bean (Phaseolus vulgaris L.) is a staple food in many developing countries, where it is used daily as a primary source of protein (Broughton et al. 2003). In these countries, the average yield of bean varieties is still very low. Limiting factors include diverse cultivation systems (intercropping beans with cereals, bananas, and root or tuber crops), restricted improved cultivar adoption, and susceptibility to biotic and abiotic stresses (Mahuku et al. 2002; Caixeta et al. 2003; Rainey and Griffiths 2005). Good sources of resistance have been found in such species as Phaseolus polyanthus Greenm. and Phaseolus coccineus L. (Busogoro et al. 1999). The use of interspecific crosses in breeding is a promising tool for expanding the genetic base of the cultivated common bean and for overcoming some agronomical constraints (Broughton et al. 2003). Numerous attempts have been made to obtain interspecific hybrids between $P$. vulgaris and the two donor species, $P$. polyanthus Greenm. and P. coccineus L.. The transfer of genetic resistance to $P$. vulgaris through interspecific hybridization is difficult because of the premature abortion of hybrid embryos. In addition, the rate of growth and final size of these hybrid embryos seems to be influenced by the parental genotypes (Geerts et al. 2002).

$P$. coccineus has been commonly used in wide crosses with $P$. vulgaris, especially to introgress genes controlling traits such as cold temperature tolerance and resistance to root rot and bean yellow mosaic virus (Schmit and Baudoin 1992). Consistent success has been limited to crosses where $P$. vulgaris is used as the female parent, but it has been reported that descendants naturally reverted to the cytoplasm donor parents after a few generations (Baudoin et al. 2004). The reciprocal cross is generally unsuccessful, although some rare successes have been reported (Nguema Ndoutoumou et al. 2007). Some data indicate that this low seed set was attributable partly to the failure of complete fertilization and partly to the slow development of interspecific hybrid embryos, endothelium proliferation, and poor endosperm development (Geerts et al. 2002). The disruption of major genes involved in embryogenesis can cause the degeneration of interspecific embryos. The transcripts of these genes can be localized in the embryo proper, in the endosperm, or in the maternal tissues around the embryo. The comprehensive and integrated mechanisms controlling gene expression during Phaseolus embryogenesis are not yet known.

Embryogenesis has been studied for a long time, including comparative morphological observations of zygotic embryo development in various plant species (Kaplan and Cooke 1997). Several techniques, such as representational differential display (Linkiewicz et al. 2004), expressed sequence tag (EST) analysis (Sun et al. 2007; Zhou et al. 2011), and the microarrays approach (Ben et al. 2005; Yang et al. 2011a), have been used in efforts to detect genes differentially expressed during zygotic embryogenesis.

The main objective of this study was to isolate and characterize cDNAs differentially expressed during Phaseolus embryogenesis. The identification of specific genes required to produce a viable embryo with a normal phenotype will improve the understanding of embryo dysfunction in Phaseolus interspecific hybrids.

Here, we report on the use and validation of the suppression subtractive hybridization ( $\mathrm{SSH}$ ) technique to isolate and study genes from Phaseolus. The SSH technique is believed to generate an equalized representation of differentially expressed genes and provides a high enrichment of differentially expressed mRNA (Diatchenko et al. 1996; Marenda et al. 2004). The efficiency and reproducibility of SSH are very useful in studies of tissue-specific, developmental, or induced differentially expressed genes (Von Stein et al. 1997; Basyuni et al. 2011; Prabu et al. 2011; Yang et al. 2011b). In addition, in some plant species, SSH has proved useful for identifying genes differentially expressed during zygotic and somatic embryogenesis (Bishop-Hurley et al. 2003; Namasivayam and Hanke 2006; Legrand et al. 2007; Tsuwamoto et al. 2007; Wang et al. 2007; Geng et al. 2009). Despite its utility and efficiency in isolating differentially expressed genes, SSH has not yet been widely applied in Phaseolus embryogenesis. In this study, differentially expressed genes during the early stage of seed development in P. vulgaris were identified using SSH. The expression patterns of the isolated genes in zygotic embryogenesis were determined by quantitative real-time reverse transcription polymerase chain reaction (RT-PCR). The paper discusses the putative roles of the identified genes.

\section{Material and Methods}

Plant Material, Hybridization, and Growth Conditions

Two cultivated genotypes, NI637 (P. vulgaris) and NI16 ( $P$. coccineus), were grown in growth chambers under the following conditions, $27^{\circ} \mathrm{C} / 23^{\circ} \mathrm{C}$ (day/night), $75 \%$ relative humidity, $580 \mu \mathrm{E} \mathrm{m}^{-2} \mathrm{~s}^{-1}$ light intensity and $12 \mathrm{~h}$ photoperiods. Several crosses were made between the two selected genotypes using either $P$. vulgaris or $P$. coccineus as the female partner. Seeds were collected each day at 3,6, 8,9 , and 12 days after pollination (DAP) from auto or cross-pollinated flowers.

RNA Isolation and cDNA Synthesis

Total RNAs were extracted from degenerated seeds of interspecific hybrids (P. coccineus $(+$ ) X P. vulgaris) and 
normal seeds (P. vulgaris), following the protocol described by Chang et al. (1993). Apart from Tris-HCl, all the reagents were prepared with DEPC-treated water. Ovules $(100 \mathrm{mg})$ were ground to a fine powder under liquid nitrogen. Then $700 \mu \mathrm{l}$ of warm $\left(65^{\circ} \mathrm{C}\right)$ extraction buffer (100 mM Tris-HCl pH 8, 25 mM EDTA pH 8, 2 M NaCl, $2 \%$ CTAB, 2\% PVP, $2 \% \beta$-mercaptoethanol) was added and the mixture was homogenized by vortexing for $2 \mathrm{~min}$. An equal volume $(700 \mu \mathrm{l})$ of chloroform/ isoamyl alcohol (24:1) was added, vortexed for $2 \mathrm{~min}$, and centrifuged for $10 \mathrm{~min}$ at $14,000 \times \mathrm{g}$ at room temperature (RT), and the supernatant was collected. For RNA precipitation, 1/4 V of $10 \mathrm{M} \mathrm{LiCl}$ was added, the mixture was inverted five times, incubated overnight at $4{ }^{\circ} \mathrm{C}$, and centrifuged for $15 \mathrm{~min}$ at $14,000 \times g\left(4^{\circ} \mathrm{C}\right)$; the pellet was re-suspended in $200 \mu \mathrm{l}$ of DEPC-treated water and then $2.5 \mathrm{~V}$ EtOH and $1 / 10 \mathrm{~V}$ of $3 \mathrm{M} \mathrm{NaAc} \mathrm{pH} 5.2$ were added. The mixture was incubated for $60 \mathrm{~min}$ at $-80^{\circ} \mathrm{C}$ and centrifuged for $15 \mathrm{~min}$ at $14,000 \times \mathrm{g}\left(4^{\circ} \mathrm{C}\right)$; the pellet was washed twice with $500 \mu \mathrm{l}$ of $70 \% \mathrm{EtOH}$, and then dried and re-suspended in 50 $100 \mu \mathrm{H}_{2} \mathrm{O}$. Poly(A) ${ }^{+}$RNA was subsequently purified using an Oligotex ${ }^{\mathrm{TM}}$ mRNA Mini Kit (Qiagen), following the manufacturer's guidelines.

Double-strand cDNAs were synthesized using the cDNA synthesis system Kit (Roche) with $2 \mu \mathrm{g}$ of mRNA. The resulting cDNAs were dissolved in $20 \mu \mathrm{l}$ of $\mathrm{H}_{2} \mathrm{O}$.

\section{Driver and Tester Preparation}

Driver and tester double-strand cDNAs were digested by $R s a \mathrm{I}$ in a $50-\mu \mathrm{l}$ reaction mixture containing $15 \mathrm{U}$ of enzymes (Fermentas) for $3 \mathrm{~h}$. The cDNAs were then phenol-extracted, ethanol precipitated, and re-suspended in $6 \mu \mathrm{l}$ of $\mathrm{H}_{2} \mathrm{O}$.

The digested tester cDNA $(1 \mu \mathrm{l})$ was diluted in $5 \mu \mathrm{l}$ of $\mathrm{H}_{2} \mathrm{O}$. A PCR-Select ${ }^{\mathrm{TM}}$ cDNA Subtraction Kit (Clontech, USA) was used for adaptor ligation: the diluted tester cDNA $(2 \mu \mathrm{l})$ was ligated to $2 \mu \mathrm{l}$ of adapter 1 and adapter 2 $(10 \mu \mathrm{M})$ in separate ligation reactions in a total volume of $10 \mu \mathrm{l}$ at $16^{\circ} \mathrm{C}$ overnight, using $15 \mathrm{U}$ of T4 ligase (Roche) in the buffer supplied by the manufacturer. After ligation, the samples were heated at $70^{\circ} \mathrm{C}$ for $5 \mathrm{~min}$ to inactivate the ligase and then stored at $-20^{\circ} \mathrm{C}$.

\section{Suppressive Subtractive Hybridization}

Suppressive subtractive hybridization (SSH) was performed with the PCR-Select ${ }^{\mathrm{TM}}$ cDNA Subtraction Kit (Clontech, USA). Two microliters of $5 \times$ hybridization buffer $[50 \mathrm{mM}$ Hepes $\mathrm{pH} 8,0.5 \mathrm{M} \mathrm{NaCl}, 0.02 \mathrm{mM}$ EDTA $\mathrm{pH} 8$ and $10 \%$ $(w / v)$ PEG 8000] were added to each of the two tubes containing adapter 1 and adapter 2-ligated tester cDNA. The solution was overlaid with mineral oil, and the samples were denatured for $1.5 \mathrm{~min}$ at $98^{\circ} \mathrm{C}$ and then allowed to anneal for $8 \mathrm{~h}$ at $68^{\circ} \mathrm{C}$. After this first hybridization, the two samples were combined and a fresh portion of heatdenatured driver in $1.5 \mu$ l of hybridization buffer was added. The sample was allowed to hybridize for an additional $10 \mathrm{~h}$ at $68^{\circ} \mathrm{C}$. The final hybridization was then diluted in $200 \mu \mathrm{l}$ of dilution buffer $(20 \mathrm{mM}$ Hepes $\mathrm{pH} 8$, $50 \mathrm{mM} \mathrm{NaCl}, 0.2 \mathrm{mM}$ EDTA), heated at $72^{\circ} \mathrm{C}$ for $7 \mathrm{~min}$ and stored at $-20^{\circ} \mathrm{C}$. Phaseolus specific elongation factor $1 \alpha$ $(E F-1 \alpha)$ primers were designed for evaluating the subtraction efficiency: EF- $1 \alpha$ F5': GTGCATTAAGTGTGGAGA and EF- $1 \alpha$ R5': TAGGCTCCTTCTCGAGCTCT.

After subtraction, two PCR amplifications were performed. The first was conducted in $25 \mu \mathrm{l}$ and contained $1 \mu \mathrm{l}$ of diluted subtracted cDNA, $0.3 \mu \mathrm{M}$ of P1 primer, $1.5 \mathrm{mM} \mathrm{MgCl} 2,0.2 \mathrm{mM}$ dNTP, $1 \mathrm{U}$ of Taq polymerase (Invitrogene) and $1 \times$ reaction buffer. PCR was conducted using the following parameters: $72^{\circ} \mathrm{C}$ for $2 \mathrm{~min}, 30$ cycles at $94^{\circ} \mathrm{C}$ for $30 \mathrm{~s}, 68^{\circ} \mathrm{C}$ for $30 \mathrm{~s}, 72^{\circ} \mathrm{C}$ for $2 \mathrm{~min}$, followed by a final extension at $72^{\circ} \mathrm{C}$ for $7 \mathrm{~min}$. The amplified products were diluted tenfold in $\mathrm{H}_{2} \mathrm{O}$. Some of the product $(1 \mu \mathrm{l})$ was then used as a template in secondary PCR with nested PCR primers PN1 and PN2. PCR was performed for 20 cycles $\left(94^{\circ} \mathrm{C}\right.$ for $30 \mathrm{~s}, 66^{\circ} \mathrm{C}$ for $30 \mathrm{~s}, 72^{\circ} \mathrm{C}$ for $\left.2 \mathrm{~min}\right)$. The product of the second PCR was analyzed on $2 \%$ agarose gel stained with ethidium bromide.

\section{Cloning and Dot-Blot Analysis of the Subtracted cDNA}

Amplified fragments from the second PCR were purified using the Gene Elute Gel Extraction Kit (Sigma), cloned into a pJET1.2/blunt vector using the Clone $\mathrm{JET}^{\mathrm{TM}}$ PCR Cloning Kit (Fermentas) and subsequently transformed into competent Escherichia coli (DH5 $\alpha$ ), plated on solid LuriaBertani (LB)/1.5 Difco agar plates supplemented with $50 \mathrm{mg} / \mathrm{l}$ ampicillin, and then grown overnight at $37^{\circ} \mathrm{C}$. Some 128 colonies were randomly selected and grown in $200 \mu \mathrm{LB}$ medium in standard 96-well plates. Then, $1 \mu \mathrm{l}$ of each bacterial culture was used to amplify the cDNA inserts in the recombinant plasmids with the primers: F5'CGACTCACTATAGGGAGAGCGGC and R5'AAGAACATCGATTTTCCATGGCAG. A 5- $\mu$ l aliquot of each PCR product was added to $0.4 \mathrm{M} \mathrm{NaOH}$ and $10 \mathrm{mM}$ EDTA in a final volume of $50 \mu \mathrm{l}$. The mixture was denatured for $10 \mathrm{~min}$ at $100^{\circ} \mathrm{C}$ and dotted onto Hybond $\mathrm{N}^{+}$nylon membranes. Altogether, two pairs of blots were prepared and subsequently cross-linked at $80^{\circ} \mathrm{C}$ for $2 \mathrm{~h}$. The blots were prehybridized with hybridization-buffer $(6 \times$ SSC, $5 \times$ Denhardt's, $0.5 \%$ SDS, and $100 \mu \mathrm{g} / \mathrm{ml}$ sheared salmon sperm DNA) for $4 \mathrm{~h}$ at $65^{\circ} \mathrm{C}$. First-strand cDNAs were incorporated with ${ }^{32} \mathrm{P}-\mathrm{dCTP}$ during reverse transcription from total RNAs (derived from tester and driver samples) using the RevertAidTM H Minus M-MuL V RT $200 \mathrm{U} / \mu \mathrm{l}$ 
(Fermentas). Hybridizations were performed overnight at $65^{\circ} \mathrm{C}$ in the hybridization buffer containing ${ }^{32} \mathrm{P}$-labeled cDNA probes, prior to autoradiographic exposure to a KODAK Storage Phosphor Screen (Bio-RAD). Finally, the membranes were scanned with a PERSONAL MOLECULAR IMAGER FX (Bio-RAD) and analyzed using the Quantity One program (Bio-RAD). The Dot blot analysis was repeated twice with two independent sets of blots.

\section{DNA Sequencing}

Plasmids were extracted using the quantum prep plasmid Miniprep Kit (BIORAD). cDNA sequencing was carried out using the GENOMELAB ${ }^{\mathrm{TM}} \mathrm{CEQ} / \mathrm{GeXP}$ DNA ANALYSIS SYSTEM (BECKMAN COULTER). Homology searches in the GenBank database were conducted using the BLASTX and BLASTN search programs (http://www.ncbi.nlm.nih.gov/BLAST/).

\section{Semi-Quantitative Reverse Transcriptase-PCR}

The specific organ expression of wild-type $P$. vulgaris was analyzed for leaves (2-week-old plants), flowers (0 DAP), stems (2-week-old plants), roots (2-week-old plants), cotyledons (3-day-old seedlings), and seeds (15 DAP). The samples were ground in liquid nitrogen, and total RNA was isolated using Trizol reagent (Invitrogen) according to the manufacturer's protocol. The amount of total RNA was determined using UV spectrophotometry. Total RNA $(5 \mu \mathrm{g})$ was treated with $1 \mathrm{U}$ of RNase-free DNAseI (Roche) for $30 \mathrm{~min}$ at $37^{\circ} \mathrm{C}$, prior to RT-PCR. The RNA was precipitated $(1 / 10(v / v) 3 \mathrm{M} \mathrm{NH} 4 \mathrm{OAc}, 2.5(v / v)$ ethanol) at $-80^{\circ} \mathrm{C}$ for $1 \mathrm{~h}$. Total RNA $(5 \mu \mathrm{g})$ was re-suspended in $11 \mu \mathrm{l}$ RNase free water and $1 \mu \mathrm{l}$ oligo $(\mathrm{dT})_{18}$ (Fermentas) and was reversed transcribed into cDNA by random priming with the RevertAidTM H Minus M-MuLV RT $200 \mathrm{U} / \mu \mathrm{l}$ (Fermentas): after $5 \mathrm{~min}$ at $70^{\circ} \mathrm{C}$, the reverse transcriptase mix $(5 \times$ reaction buffer, RibolockTM
Ribonuclease inhibitor $20 \mathrm{U} / \mu \mathrm{l}, 10 \mathrm{mM}$ dNTP mix) was added and kept at $37^{\circ} \mathrm{C}$ for $5 \mathrm{~min}$; total pre-treated RNA was reverse transcribed at $42^{\circ} \mathrm{C}$ for $1 \mathrm{~h}$. Primer pairs were designed using Primer3 Input (version 0.4.0) software (Rozen and Skaletsky 2000) (http://frodo.wi.mit.edu/primer3/) (Table 1). The $18 \mathrm{~S}$ gene was used as a control for RNA loading.

Fragments were amplified from these cDNA pools using Taq DNA polymerase (Invitrogen).

PCR amplification was performed using the following program: $3 \mathrm{~min}$ at $94^{\circ} \mathrm{C}, 30$ cycles for $30 \mathrm{~s}$ at $94^{\circ} \mathrm{C}, 30 \mathrm{~s}$ at $55-60^{\circ} \mathrm{C}$ and $30 \mathrm{~s}$ at $72^{\circ} \mathrm{C}$. An elongation step of $72^{\circ} \mathrm{C}$ for 2 min was conducted for the last cycle. Reactions were performed in a Minicycler (BioRad iCycler) thermal cycler. The experiments were repeated three times. The amplified PCR products $(15 \mu \mathrm{l})$ were electrophoresed on $1 \%(w / v)$ agarose gel, stained with ethidium bromide, and then scanned using an image analyzer.

Measuring Temporal Expression of Select Clones by Real-Time RT-PCR Analysis

Total RNA from the abortive and normal seeds of $P$. vulgaris and $P$. coccineus were reverse transcribed using the First Strand cDNA Synthesis Kit for RT-PCR (AMV) (Roche), following the supplier's instructions. For cDNA synthesis, $5 \mu \mathrm{g}$ of total RNA from each time point was used as a template in a $20-\mu l$ reaction mixture. Each reaction mixture contained $1 \times$ buffer reverse transcriptase (RT), $0.5 \mathrm{mM}$ deoxynucleoside triphosphate, $1 \mu \mathrm{M}$ oligo (dT) primer, $10 \mathrm{U}$ of RNase inhibitor, and $4 \mathrm{U}$ of AMV reverse transcriptase. The reaction mixture was incubated for $60 \mathrm{~min}$ at $37^{\circ} \mathrm{C}$. cDNA was diluted $1: 10$, and $5 \mu \mathrm{l}$ of the dilution was used in a SYBER Green RT-PCR (Fermentas).

Real-time PCR experiments were carried out using SYBER Green chemistry for amplicon detection. The SYBER Green assays were performed on the ABI7500 FAST real-time PCR instrument (Applied Biosystems). The
Table 1 The primers used in the RT-PCR analysis

\begin{tabular}{lll}
\hline Target & Forward primer $\left(5^{\prime}\right.$ to $\left.3^{\prime}\right)$ & Reverse primer $\left(5^{\prime}\right.$ to $\left.3^{\prime}\right)$ \\
\hline GW884166 & TTACAGAGAGGGCCCAGAGA & GCAAGATGTTTACCGGAGGA \\
GW884169 & GGTGCTCTAACCAGGGTGTC & TTCCATGGCAGCTGAGAATA \\
GW884170 & ACAGGCTGATGACTCCCAAG & CATCGATTTTCCAGTTGCAG \\
GW884171 & GCGACAGTGCAATCTCCAAC & TTCCATGGCAGCTGAGAATA \\
GW884172 & GCACATGTGTGCTATCCTGA & ACAAAACGCTGGCTTCTGAT \\
GW884173 & CAACGAAAAGGACAGCGAAC & GCGGGTCGAGCTTGTAGAG \\
GW884174 & CGGAAAAAGCACCATCCAGT & TTCCATGGCAGCTGAGAATA \\
GW884175 & GAACCCTTGGGACCTTCTTC & GGCGATAACAGGCTGATGAC \\
GW884176 & ACTCACAACCGCGTCTCC & AGTCGGATACACCGGCATAG \\
GW884177 & CCAATCACTATTGGGCTCGT & GGTGAACGTCGGTATTAAGCA \\
\hline
\end{tabular}


amplification of target genes, along with a template-minus control, was performed in triplicate in a 96-well plate. Each $20 \mu \mathrm{l}$ reaction mixture contained $5 \mu \mathrm{l}$ cDNA, $10 \mu \mathrm{l} 2 \times$ SYBER Green Master Mix and $0.3 \mu \mathrm{M}$ (each) of forward and reverse primers. The primers were designed using Primer3 software (they are listed in Table 1). The cycling conditions for amplification included a $10 \mathrm{~min}$ cycle at $95^{\circ} \mathrm{C}$ followed by 40 cycles at $95^{\circ} \mathrm{C}$ for $10 \mathrm{~s}, 60^{\circ} \mathrm{C}$ for $30 \mathrm{~s}$, and $82^{\circ} \mathrm{C}$ for $30 \mathrm{~s}$. Fluorescence was measured at $82^{\circ} \mathrm{C}$ during each cycle. Real-time PCR data were plotted using 7500 Fast System Software (Applied Biosystems) by taking the mean of three replicates per time point. The relative difference in expression was measured using the Basic $\Delta C_{\mathrm{T}}$ method.

\section{Results}

Generating an SSH Library from Interspecific Hybrids and Wild-type Seed Development

To identify genes differentially expressed in Phaseolus embryogenesis, an SSH library was constructed using cDNA from abortive seeds (interspecific hybrids; 12 DAP) as the driver, and cDNA pooled from normal seeds at 3, 6, 8, 9, and 12 DAP as the tester. These five periods corresponded to the early globular, globular, heart, torpedo, and cotyledon stages of embryo development, respectively (Abid et al. 2009). Total RNA was isolated and appeared undergraded on $1 \%$ agarose gel (Fig. 1a). Double-strand cDNA was synthesized and, after two rounds of subtraction, the subtraction efficiency was evaluated by detecting the housekeeping gene elongation factor $1 \alpha(\mathrm{EF}-1 \alpha)$ in both the subtracted and non-subtracted cDNA pools, using PCR amplification. If the subtraction was efficient, the abundance of housekeeping genes in the subtracted library was greatly reduced compared with the unsubtracted tester control. As shown in Fig. 1b, the EF- $1 \alpha$ fragment was clearly detectable in the unsubtracted tester after 23 cycles of amplification, whereas in the subtracted library, it required 25 cycles of amplification, indicating that cDNA homologous to both the tester and the driver had been subtracted. The subtractive product was amplified by PCR using oligonucleotides that were complementary to adapters 1 (PN1 and PN2). Figure 1c shows the electrophoretic analysis of the final PCR products. There are clear differences between the subtracted and unsubtracted cDNA libraries. The observable PCR products in the unsubtracted and subtracted libraries ranged between 300 and 2,000 bp and 300 and 1,500 bp, respectively (Fig. 1c). The difference in the amplification patterns between subtracted and unsubtracted cDNAs indicates a successful subtraction.

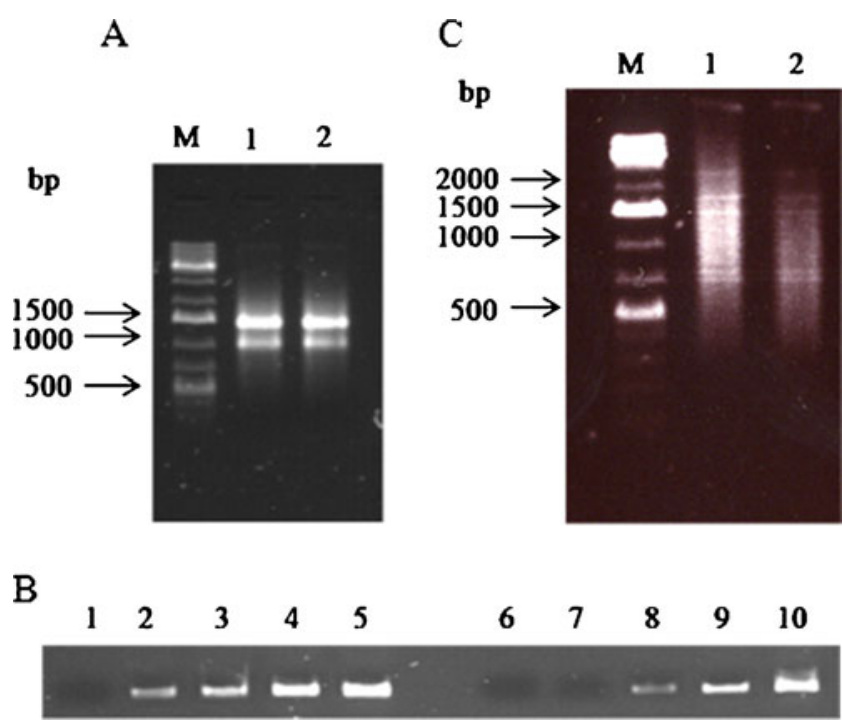

Fig. 1 The suppression subtractive hybridization (SSH) was conducted using cDNA from abortive seeds as the driver and cDNA from normal seed as the tester. a Total RNA of $P$. vulgaris (lane 1 ) and $P$. coccineus (female symbol) X $P$. vulgaris (lane 2). Lane M: DNA size markers. b PCR amplification of EF1 $\alpha$ to analyze the efficiency of SSH: 1-5 were amplified from cDNA template before subtraction and 6-10 after subtraction. Lanes 1 and 6 were the result of 20 amplification cycles, lanes 2 and 7, 23; lanes 3 and 8, 25; lanes 4 and $9 ; 28$; lanes 5 and $10 ; 30$. c Electrophoresis pattern of the secondround PCR with the unsubtracted (lane 1) and subtracted cDNA as template (lane 2). Lane M: DNA size markers

\section{PCR Amplification and Dot-Blot Screening of SSH Clones}

The secondary PCR products of the SSH cDNA library were inserted into a pJET 1.2/blunt vector and transformed into Escherichia coli $(\mathrm{DH} 5 \alpha)$. A total of 72 recombinant clones were obtained after amplification using PCR and examination using electrophoresis. Most clone inserts ranged from 200 to $600 \mathrm{bp}$, averaging $300 \mathrm{bp}$ per fragment (Fig. 2). The PCR products were spotted on hybond-N ${ }^{+}$ nylon membranes and hybridized with probes prepared with unsubtracted tester/driver cDNA. Differences in the intensity of hybridization signals were observed for many clones (Fig. 3). Sixteen clones showing positive or stronger signals when hybridized with the tester cDNA, but having no or weaker signals with the driver cDNA, were identified and sequenced. Fourteen other clones showing a low difference signal between driver and tester clones were also sequenced.

Sequence Analysis and Identification of Differentially Expressed Genes

To identify a putative set of genes involved in Phaseolus embryogenesis, and to characterize function and redundancy among the putative positive clones, 30 selected individual clones were single run sequenced. After an alignment search, 
Fig. 2 PCR analysis of clones from the subtracted library. Lanes 1-18: PCR products from different clones. Lane $M$ : DNA size markers
$\begin{array}{lllllllllllllllllll}M & 1 & 2 & 3 & 4 & 5 & 6 & 7 & 8 & 9 & 10 & 11 & 12 & 13 & 14 & 15 & 16 & 17 & 18\end{array}$

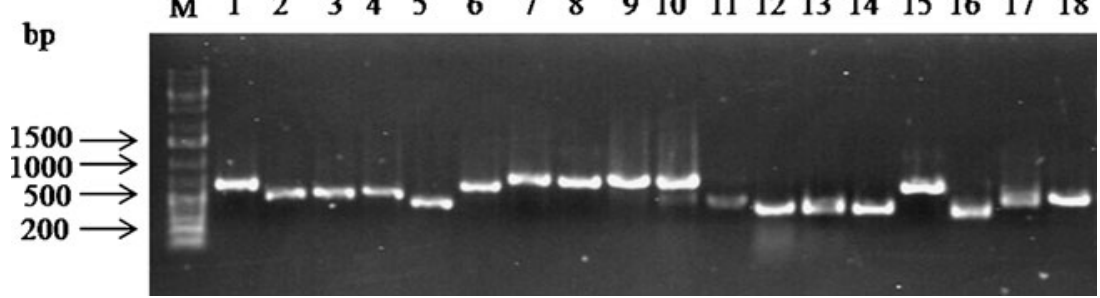

12 sequences were identified as unique genes, and the remaining18 sequences as repeated clones. All 12 cDNA sequences were submitted to the GenBank database (see Table 2 for the accession numbers). Using the BLASTn and BLASTx programs, the 12 cDNA sequences were used as queries to search in the GenBank database for homologies; the results are shown in Table 2. For only one EST clone (GW 884177) database searches failed to find a significant similarity with a sequence coding for a gene of known function, suggesting that this clone corresponds to an unidentified gene and could therefore be novel. The other EST clones were shown to be related to genes of known functions registered in databases. Our library contained several genes previously reported to be associated with plant zygotic embryo development, such as storage protein activator (SPA), acetyl-CoA carboxylase (ACCase), and pentatricopeptide repeat-containing protein (PPR). The library also included cDNAs not previously reported to be associated with embryogenesis, such as those coding for the esterase/lipase/thioesterase (ELT) protein or the hydrolase protein. Also in this library was cDNA coding for cell wall biosynthesis as proline-rich protein (PRP). Other genes were assigned to the ribosomal structure, biogenesis categories, and energy production such as NADH dehydrogenase, cell wall hydrolase, and peptidase M16-like protein (metalloproteases).
The most represented genes in our libraries are SPA and PPR, with five and four ESTs, respectively. BLAST analysis also showed that some cDNA clones, such as PPR and SPA, presented a high homology with two or more cDNAs isolated from different species but encoding for the same function.

\section{Tissue-Specific Expression of the Selected ESTs}

As an initial characterization of gene expression in Phaseolus plants, an expression pattern of the 10 selected ESTs listed in Table 2 was examined using RT-PCR (Fig. 4). Total RNA was isolated from leaves, flowers, stems, roots, cotyledons, and seeds from common bean plants. All selected ESTs showed high expression in seed tissues but less or no expression in vegetative tissues. For the PPR, transcripts were detected exclusively in seed tissues, with no expression detected in vegetative tissues. SPA and cell wall hydrolase were present at high levels in seed and flower tissues. ACCase and ELT were also detected at low levels in leaf and flower tissues, but no expression was detected in other tissues. Peptidase M16like protein showed high expression in seed, stem, root, and cotyledon tissues and low expression in leaves and flowers. NADH dehydrogenase had about the same level of expression in the different vegetative tissues. For 18S, a
Fig. 3 Dot-blot analysis of clones from the subtracted library. cDNA from the driver and the tester were used as probes. Differentially expressed clones are marked with arrows

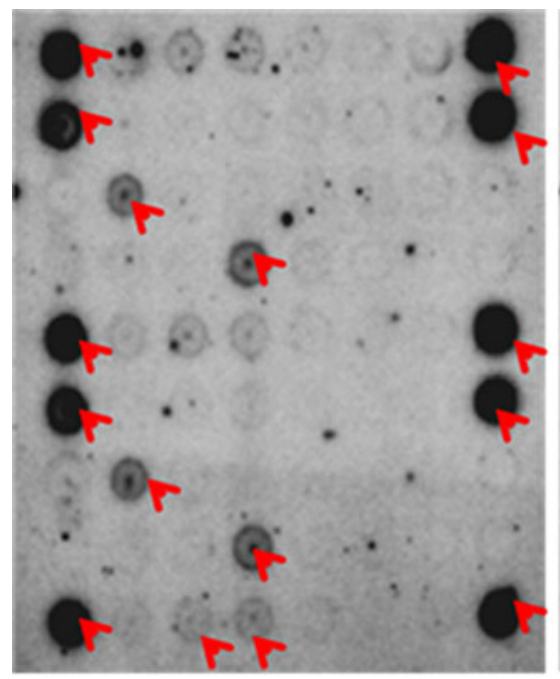

Tester

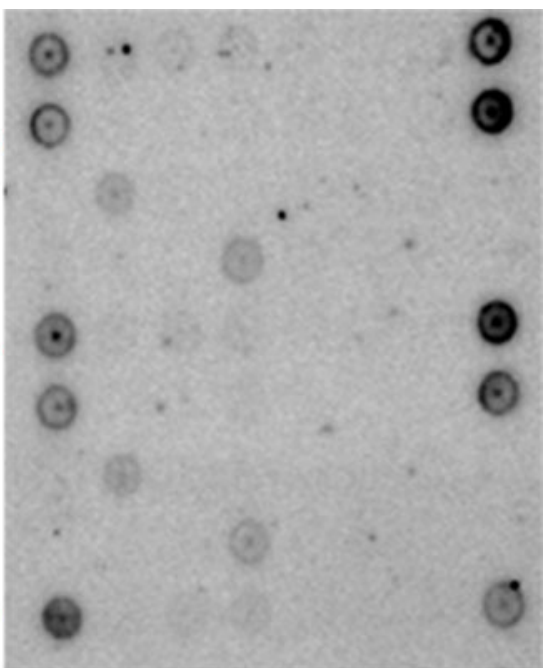

Driver 
Table 2 Specification of the identified ESTs and their putative function

\begin{tabular}{|c|c|c|c|c|c|c|c|}
\hline Clone & Length (bp) & $\begin{array}{l}\text { Number of } \\
\text { identical } \\
\text { clones }\end{array}$ & $\begin{array}{l}\text { Homology } \\
\text { analysis }\end{array}$ & Putative identity (Accession no) & $\begin{array}{l}\text { Identities } \\
\text { (aa/aa or bp/bp) }\end{array}$ & E-value & $\begin{array}{l}\text { Accession no of } \\
\text { EST in Genbank }\end{array}$ \\
\hline Pc_SSh1 & 259 & 5 & BLASTn & $\begin{array}{l}\text { Storage protein activator ( Triticum aestivum) } \\
\text { FM242578.1 }\end{array}$ & $157 / 167(94 \%)$ & $2 \mathrm{E}-64$ & GW884166 \\
\hline Pc_SSh2 & 212 & 2 & BLASTn & $\begin{array}{l}\text { NADH dehydrogenase subunit } 5 \text { (Cucurbita } \\
\text { pepo) GQ856148.1 }\end{array}$ & $133 / 136(97 \%)$ & $7 \mathrm{E}-58$ & GW884170 \\
\hline Pc_SSh3 & 216 & 1 & BLASTn & $\begin{array}{l}\text { Esterase/lipase/thioesterase family protein } \\
\text { (Glycine } \max \text { ) BM } 143356\end{array}$ & $112 / 130(87 \%)$ & 4E-41 & GW884171 \\
\hline Pc_SSh4 & 256 & 4 & BLASTn & $\begin{array}{l}\text { Pentatricopeptide repeat-containing protein } \\
\text { (Phaseolus coccineus) CA911930.1 }\end{array}$ & $127 / 130(97 \%)$ & $1 \mathrm{E}-54$ & GW884172 \\
\hline Pc_SSh5 & 292 & 1 & BLASTx & $\begin{array}{l}\text { Peptidase M16-like protein (Sphingopyxis } \\
\text { alaskensis) YP } 617011.1\end{array}$ & $53 / 69(76 \%)$ & $7 \mathrm{E}-26$ & GW884173 \\
\hline Pc_SSh6 & 212 & 1 & BLASTx & $\begin{array}{l}\text { Hydrolase, alpha/beta fold family protein } \\
\text { (Sorghum bicolor) XP_002468316.1 }\end{array}$ & $20 / 40(50 \%)$ & $1 \mathrm{E}-05$ & GW884174 \\
\hline Pc_SSh7 & 133 & 3 & BLASTn & $\begin{array}{l}\text { Cell wall-associated hydrolase (Coffea } \\
\text { canephora) GW397447.1 }\end{array}$ & $129 / 131(99 \%)$ & $3 \mathrm{E}-58$ & GW884175 \\
\hline Pc_SSh8 & 247 & 2 & BLASTx & $\begin{array}{l}\text { Proline-rich family protein (Arabidopsis } \\
\text { thaliana) NP_176303.1 }\end{array}$ & $26 / 73(35 \%)$ & $4 \mathrm{E}-06$ & GW884176 \\
\hline Pc_SSh9 & 308 & 2 & BLASTx & $\begin{array}{l}\text { Unknown hypothetical protein (Opitutaceae } \\
\text { bacterium) ZP_03725668.1 }\end{array}$ & $28 / 80(35 \%)$ & 4E-09 & GW884177 \\
\hline Pc_SSh10 & 282 & 4 & BLASTn & $\begin{array}{l}\text { Glycine max cDNA } \bar{N} \text {, clone: GMFL01-47-K21 } \\
\text { (Glycine max) AK245973.1 }\end{array}$ & $109 / 130(83 \%)$ & $6 \mathrm{E}-26$ & GW884167 \\
\hline Pc_SSh11 & 216 & 2 & BLASTn & $\begin{array}{l}\text { Ribosomal protein S26 (Cucurbita pepo) } \\
\text { GQ856148.1 }\end{array}$ & $134 / 141(95 \%)$ & $1 \mathrm{E}-51$ & GW884168 \\
\hline Pc_SSh12 & 223 & 3 & BLASTn & $\begin{array}{l}\text { (Acc-2) cytosolic acetyl-CoA carboxylase } \\
\text { (Aegilops tauschii) EU660891.1 }\end{array}$ & $157 / 167(94 \%)$ & $3 \mathrm{E}-63$ & GW884169 \\
\hline
\end{tabular}

similar level of expression was detected in all tissues examined.

Confirmation of the Differential Expression of Selected Genes by Real-Time PCR

To evaluate the viability of the SSH library and Dot blot analysis, we performed real-time PCR analysis. Total RNA pools originally used as samples for constructing libraries were examined for ten selected ESTs, and the Pv 18S rRNA gene was used as an internal control.

In general, the results of real-time PCR were consistent with the differential screening data obtained by Dot blot analysis, but the Dot blot data sometimes underestimated or overestimated the real expression levels of the genes. The discrepancies observed between the two methods probably derive from cross-hybridizations that could occur on arrays between sequence-related genes from the same multigene family (Miller et al. 2002).

Real-time PCR data (Fig. 5) revealed that ESTs with significant homologies to PPR, SPA, ACCase, NADH dehydrogenase, cell wall hydrolase, PRP, hydrolase alpha/ beta fold protein, and putative protein encoding to ELT were $8.09,8.49,7.87,1.2,2.9,1.54,1.64$, and 14.56 times over-expressed, respectively, in the maternal parent compared with interspecific hybrids. Peptidase M16-like protein and the unknown putative protein were 0.54 and 0.32 times under-expressed in the maternal parent, respectively. No expression was shown for the PPR gene in interspecific hybrids. In addition, SPA, PPR, ELT, and ACCase gene expression was the most affected in interspecific hybrids during seed development, whereas PRP and cell wall hydrolase genes were the least affected. For the Hyd gene, the reduction of expression was minor compared with the parental samples.

\section{Differential Expression of Selected ESTs During Seed Development by Real-Time PCR}

In order to evaluate the differential expression of the subtracted genes during Phaseolus embryogenesis, the expression pattern of six selected genes related to the transcription factors and/or signal transduction and one gene with an unknown function was investigated using real-time PCR (Fig. 6). The pattern expression of the target gene transcripts was examined at different stages of common bean embryo development: $3,6,8$, 9, and 12 DAP.

All the genes were differentially expressed during seed development in P. vulgaris. SPA was highly expressed during embryogenesis from the early globular stage (3 DAP) to the cotyledon stage (12 DAP), with the highest expression at 6, 8, and 9 DAP. The expression of the PRP gene and the sequence coding for the unknown hypothetical protein was higher in the early globular stage (3 DAP) and 


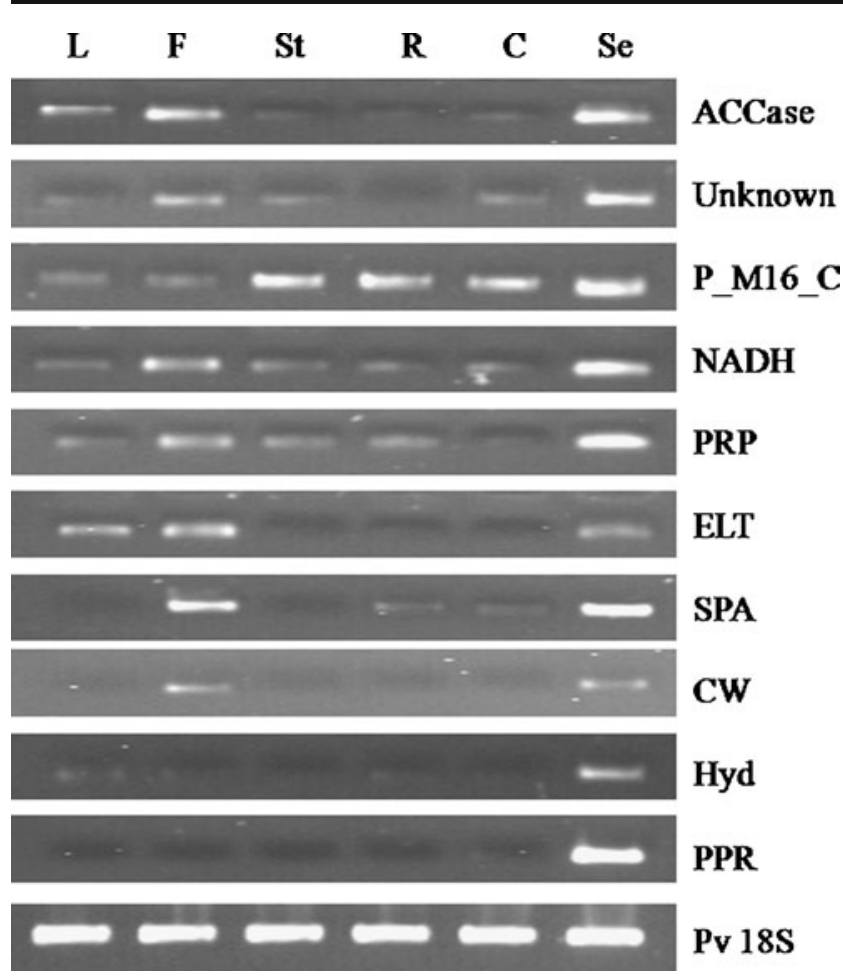

Fig. 4 RT-PCR of selected genes from common bean tissues: SPA (GW884166), NADH (GW884170), ELT (GW884171), PPR (GW884172), P_M16_C (GW884173), Hyd (GW884174), CW (GW884175), PRP (GW884176), Unknown hypothetical protein (GW884177) and ACCase (GW884169). Leaves $(L)$, flowers $(F)$, stems $(S t)$, roots $(R)$, cotyledons $(C)$, and seeds $(S e)$. Lower lanes: common bean $18 \mathrm{~S}$ internal control

lower in other stages. ACCase and ELT showed specific expression during seed development in P. vulgaris. Their expression kinetic was wave-shaped, with an initial overexpression peak at about 6 DAP and the second highest peak at about 9 DAP (Fig. 6). RT-PCR analysis revealed, however, that PPR gene expression was at its maximum at 3 DAP, although at 6 DAP, expression decreased rapidly and then increased to reach high levels at a later stage (12 DAP).

\section{Discussion}

In the Phaseolus genus, early interspecific embryo abortion is attributed to several factors, such as nutritional barriers related to a deficient endosperm or suspensor development, endothelium proliferation and, to some extent, hypertrophy of the vascular elements (Geerts et al. 2002; Toussaint et al. 2004). However, little is known about the molecular process that alters interspecific embryo development and leads to seed abortion. The alteration in some genes involved in normal embryo development disrupts embryo formation and leads to seed abortion (Tzafrir et al. 2004). Transcripts of these genes can be localized in the embryo

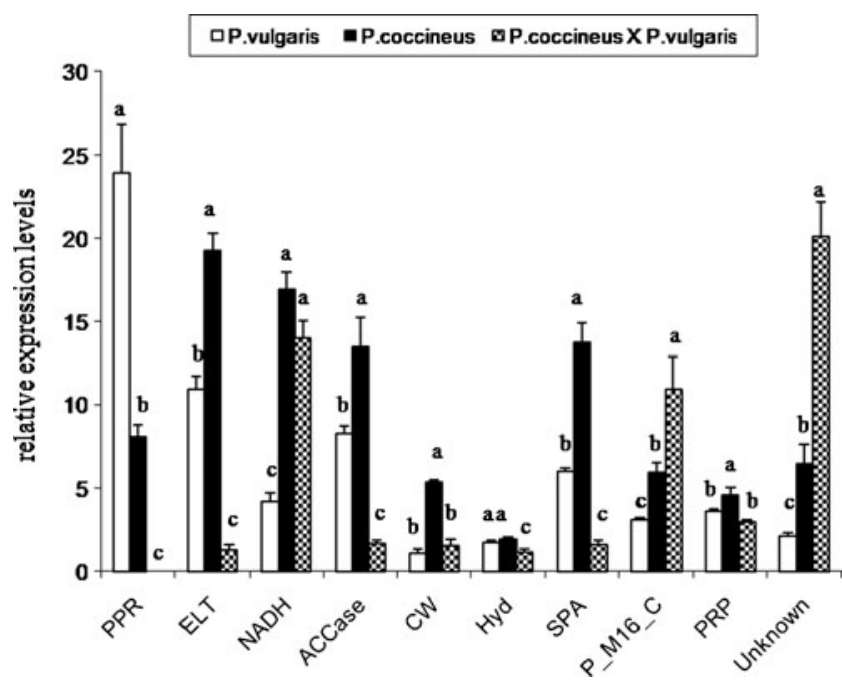

Fig. 5 Relative expression ratios of the transcripts of ten SSH candidates during seed development (six DAP) in P. vulgaris, $P$. coccineus, and interspecific hybrid ( $P$. coccineus $\times P$. vulgaris) genotypes. SPA (GW884166), NADH (GW884170), ELT (GW884171), PPR (GW884172), P_M16_C (GW884173), Hyd (GW884174), CW (GW884175), PRP (GW884176), Unknown (GW884177), and ACCase (GW884169). The relative mRNA levels of individual selected genes were normalized to the housekeeping gene 18S. Data shown represent mean values obtained from three independent amplification reactions and the error bars indicate standard deviation. Significant difference $(P<0.05)$ detected by Tukey's multiple comparison test is shown by different letters above the bars

proper, in the endosperm, or in the maternal tissues around the embryo.

To gain insight into the molecular mechanism of embryo dysfunction from Phaseolus interspecific hybrids, we attempted to identify genes required in Phaseolus embryo development. The expression profiles of seed development in the Phaseolus interspecific hybrids P. coccineus (NI16) $\mathrm{X} P$. vulgaris (NI637) and the maternal parent $(P$. coccineus) were compared using SSH analysis. Twelve differentially expressed transcripts were examined. Eight transcripts showed homology with previously described genes from plant species such as $P$. coccineus, Glycine max, Arabidopsis thaliana, and Triticum aestivum. Two transcripts showed great homology with functional protein in fungi species. Genes identified in this study were related to many aspects of plant cell metabolism, such as signal transduction, metabolism of amino acids, secondary metabolites, saccharides, and fatty acids. Mutation in these genes affects seed development and the embryogenesis process (Baud et al. 2003; Lara et al. 2003; Suda and Giorgini 2003; Schaller 2004; Saha et al. 2007). The low number of repeated annotated genes represented by single ESTs identified in this work indicates an efficient normalization of the libraries, as only the PPR and SPA genes were represented by more than four ESTs. 

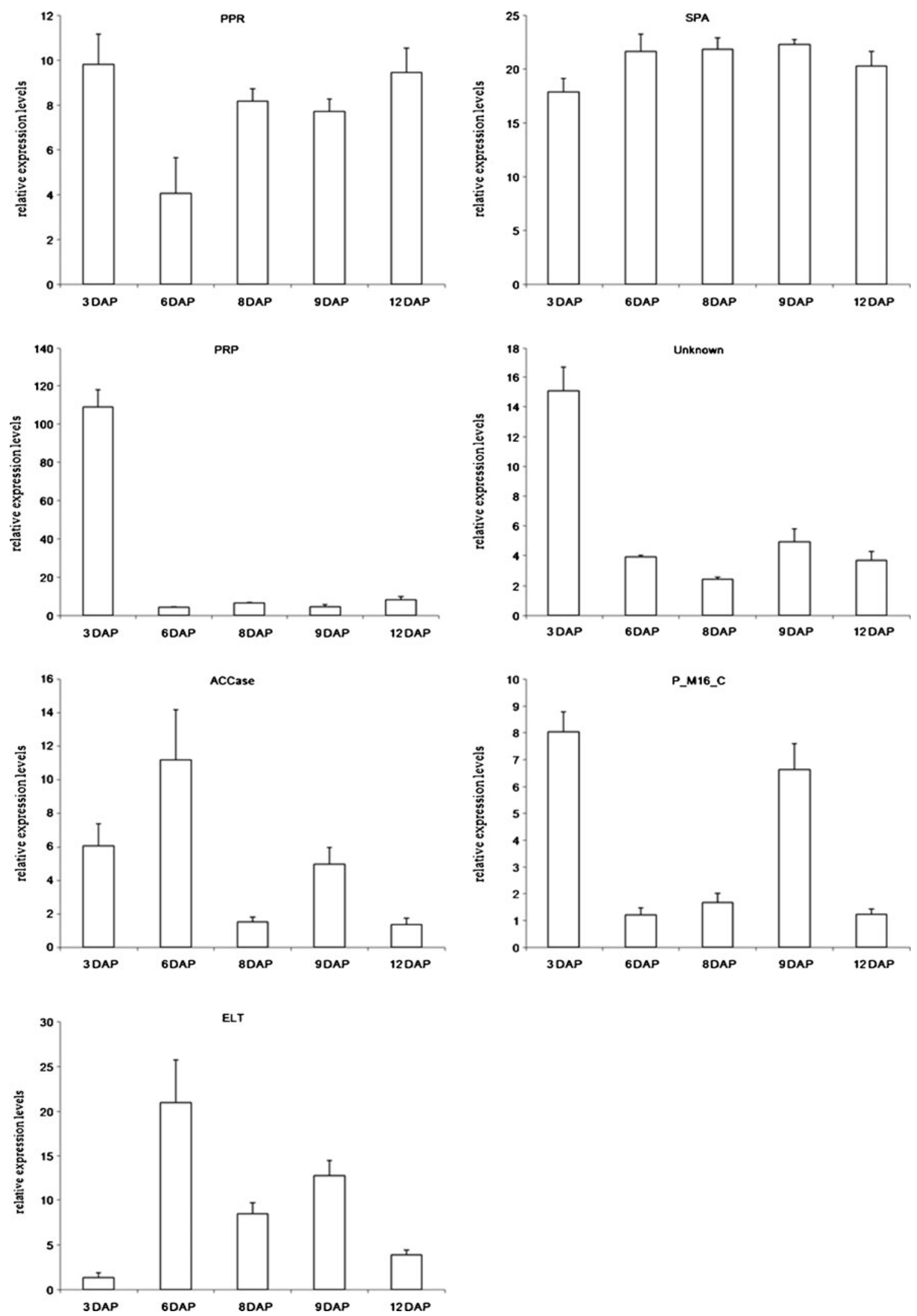

Fig. 6 Expression pattern of SPA (GW884166), PPR (GW884172), PRP (GW884176), ELT (GW884171), P_M16_C (GW884173), unknown hypothetical protein (GW884177), and ACCase (GW884169) during

common bean seed development by real-time RT-PCR. The relative mRNA levels of individual selected genes are normalized with respect to the housekeeping gene $\mathrm{Pv} 18 \mathrm{~S}$ in different tissues 
Real-time PCR showed reduced expression in seven selected genes in interspecific hybrids compared with the maternal parent: this was particularly so for PPR, SPA, and ACCase. In addition, these genes are involved in normal embryo morphogenesis. ACCase catalyzes the ATPdependent formation of malonyl-CoA from acetyl-CoA and bicarbonate, which is used in the plastid for fatty acid synthesis and in the cytosol for various biosynthesis pathways, including fatty acid elongation (Konishi and Sassaki 1994). Baud et al. (2003) showed that ACCase 1 is essential for $A$. thaliana embryo development and plays a key role in apical development. Mutants lacking ACCase are embryonically lethal and showed alteration during the cell differentiation process (Baud et al. 2004). ACCase also appears to be a key factor in embryo development, although it encodes for a common and widespread enzyme of carbon metabolism.

Seed storage proteins (SSP) are specifically synthesized in developing seeds, in both the endosperm and the embryo in monocotyledons, whereas in dicotyledonous plants, the endosperm is commonly re-absorbed as maturation proceeds, and storage proteins are preferentially accumulated in the embryo (Lara et al. 2003). The bipartite endosperm box endosperm motif (EM), the GCN4-like motif (GLM), and the ACAA motif are important regulatory elements, often found in the promoters of endosperm and embryonicspecific genes, such as SSP genes (Müller and Knudsen 1993). These cis-elements are bound by transcription factors such as SPA, a seed-specific basic leucine zipper that activates transcription from the EM and GLM motif required for endosperm-specific gene expression (Lara et al. 2003; Albani et al. 1997). Other transcription factors regulating seed-specific expression have been well documented for some plant species, such as Hordeum vulgare (BLZ1 and BLZ2), Oryza sativa (RISBZ1 and RITA1), Sorghum bicolor (SBO2), and A. thaliana (AtbZIP). In Zea mays, OPAQUE2 (O2) has been shown to encode a basic domain /leucine zipper transcriptional activator that regulates a subset of zein storage protein genes (Schmidt et al. 1992). Mutation affecting endosperm storage protein in several cereal species is known to cause developmental disruptions, severely altering storage protein deposition and endosperm development (Boston et al. 1991).

PPR genes encode RNA-binding proteins that play a key role in post-transcriptional processes (including RNA editing, RNA splicing, RNA cleavage, and translation) within mitochondria and chloroplasts (Schmitz-Linneweber and Small 2008). In addition, several PPR proteins have been shown to act as fertility restorer genes in commercially important cytoplasmic male sterility systems (Bentollia et al. 2002). Interestingly, mutant PPR proteins exhibit defects in embryogenesis and the patterning of embryo morphology, resulting in embryo lethality (Cushing et al. 2005). These data suggest that some PPR genes play an essential role in plant embryo development. In $A$. thaliana, the loss-offunction phenotype of embryo-defective 175 (emb175) and CLUTAMINE-RICH PROTEIN23 ( grp23) mutants altered in PPR expression produces embryonic growth arrests at a very early stage, before the globular to heart transition and at the 16-celled dermatogens state, respectively (Cushing et al. 2005; Ding et al. 2006). The mutation in Arabidopsis AtPPR4, a homolog of maize PPR4, causes embryo lethality (Schmitz-Linneweber et al. 2005). More recently, Gutierrez-Marcos et al. (2007) showed that empty pericarp4 encodes a mitochondrion-target pentatricopeptide repeat protein required for maize seed development. Mutation in this gene confers a seed-lethal phenotype; the endosperm is severely impaired, with highly irregular differentiation of transfer cells in the nutrient-importing basal endosperm.

Eight represented genes in our libraries show homology with sequences from other plant species such as $A$. thaliana and G. max, encoding mitochondrial proteins such as NADH dehydrogenase, peptidase M16-like protein and putative ELT. Lurin et al. (2004) suggested that several mitochondrial mutant genes showed alteration in embryo development. These data suggests that mitochondria and plastids in general, are essential for providing energy to plant cells, particularly to the actively dividing cells of the embryo.

Another interesting result is the identification of a gene putatively encoding for basic PRP. PRP is considered to be a structural component of the cell wall, has been shown to be involved in many signaling pathways (Showalter 2001; Williamson 1994), and is reported to be essential for the formation of somatic embryos in Cichorium intybus (Chapman et al. 2000). A particular PRP from maize $(z m H y P R P)$ is specifically expressed in embryos (JoséEstanyol et al. 1992). Its expression is associated with early embryo stages, marking the initial steps of scutellum development, and it has been shown to be accumulated mostly during cell division.

Many of the genes mentioned above are similar to already known embryogenesis-related genes. In order to further confirm the expression pattern of those genes and to characterize their function so as to understand their role in the early stage of Phaseolus embryogenesis, six genes (PPR, SPA, PRP, ACCase, P_M16_C, and ELT) related to the transcription factors and/or signal transduction and one gene with unknown function were selected, and the expression profiles were investigated using real-time RTPCR at different stages of seed development in P. vulgaris. Interestingly, RT-PCR analysis revealed that the expression of some genes, such as PPR and PRP, was clearly detected at early stages and decreased at later stages of seed development in P. vulgaris, suggesting a potential role of these selected genes at an early stage of common bean embryogenesis. Many of these genes were shown to be expressed in the zygotic embryos of other plant species. In 
maize and A. thaliana, PPR is expressed in vegetative and reproductive tissues, at 6 and 12 DAP (Gutierrez-Marcos et al. 2007; Saha et al. 2007). Our data showed that PPR was expressed only in seed tissues at different developmental stages. This result suggests a possible key role of PPR during common bean embryogenesis.

In A. thaliana, ACCase transcripts were present in all tissues analyzed at various stages of seed development. The highest expression levels were observed at 6 DAP (Baud et al. 2003). These data are in agreement with our results. However, we revealed a low transcript of ACCase at 12 DAP. This expression pattern may be correlated with the accumulation of fatty acid at this stage of seed development in P. vulgaris.

In wheat, SPA, which is a member of the basic leucine zipper (bZIP) regulators of endosperm-specific gene expression such as seed storage protein (SSP), showed an early expression in the developing seed (Albani et al. 1997). In Arabidopsis AtZIP10 and AtZIP25, genes are expressed in roots, shoots, rosette leaves, and flowers, but intense signals are revealed particularly at the early and later stages of seed development. We showed that SPA is expressed in reproductive organs such as flowers, and is strongly up-regulated at different stages of seed development in P. vulgaris, suggesting that the SPA gene might play an important role during seed development in $P$. vulgaris.

\section{Conclusion}

In this study, SSH was performed to screen genes that were differentially expressed in abortive and normal Phaseolus seed development. The expression pattern of the genes identified in this study (SPA, PPR, PRP, ELT, P_M16_C, ACCase, and the gene encoding an unknown hypothetical protein) suggested that these genes could play a critical role during seed development in $P$. vulgaris.

In further experiments, which will be conducted to clarify whether the signals detected in real-time PCR were derived specifically from the embryo tissues or from other seed tissues, some of the genes revealed in our investigations, particularly SPA, PPR, and ACCase, will be used as probes to follow the spatial expression pattern during seed development in P. vulgaris using the in situ hybridization (ISH) technique for detecting gene expression at the cellular level (Bayer et al. 2009).

\section{References}

Abid G, Muhovski Y, Jacquemin JM, Silue S, Toussaint A, Baudoin JP (2009) Abortive seed development in common bean (Phaseolus vulgaris L.). Bean Improvement Cooperative 52:8-9
Albani D, Hammond-Kosack MCU, Smith C, Conlan S, Colot V, Holdsworth M, Bevan MW (1997) The wheat transcriptional activator SPA: a seed-specific bZIP protein that recognizes the GCN4-like motif in the bifactorial endosperm box of prolamin genes. The Plant Cell 9:171-184

Basyuni M, Kinjo Y, Baba S, Shinzato N, Iwasaki H, Siregar EBM, Oku H (2011) Isolation of salt stress tolerance gene from roots of mangrove plant, Rhizophora stylosa Griff., using PCR-based suppression subtractive hybridization. Plant Mol Biol Rep 29:533-543

Baud S, Guyon V, Kronenberger J, Wuilleme S, Miquel M, Caboche M, Lepiniec L, Rochat C (2003) Multifunctional acethyl-CoA carboxylase 1 is essential for very long chain fatty acid elongation and embryo development in Arabidopsis. Plant J 33:75-86

Baud S, Bellec Y, Miquel M, Bellini C, Caboche M, Lepiniec L, Faure JD, Rochat C (2004) gurke and pasticcino3 mutants affected in embryo development are impaired in acetyl-CoA carboxylase. EMBO reports 5:515-520

Baudoin JP, Silué S, Geerts P, Mergeai G, Jacquemin JM, Toussaint A (2004) Interspecific hybridization with Phaseolus vulgaris L.: embryo development and its genetics. In: Pandalai SG (ed) Recent research development in genetics and breeding. Research Signpost, India, pp 349-364

Bayer M, Nawy T, Giglione C, Galli M, Meinnel T, Lukowitz W (2009) Paternal control of embryonic patterning in Arabidopsis thaliana. Science 323:1485-1488

Ben C, Hewezi T, Jardinaud MF, Bena F, Ladouce N, Moretti S, Tamborindeguy C, Liboz T, Petitprez M, Gentzbittel L (2005) Comparative analysis of early embryonic sunflower cDNA libraries. Plant Mol Biol 57:255-270

Bentollia S, Alfonso AA, Hanson MR (2002) A pentatricopeptide repeatcontaining gene restores fertility to cytoplasmic male-sterile plants. PNAS 16:10887-10892

Bishop-Hurley SL, Gardner RC, Walter C (2003) Isolation and molecular characterization of genes expressed during somatic embryo development in Pinus radiata. Plant Cell Tissue Organ Cult 74:267-281

Boston RS, Fontes EBP, Shank BB, Wrobel RL (1991) Increased expression of the maize immunoglobulin binding protein homo$\log$ b-70 in three zein regulatory mutants. Plant Cell 3:497-505

Broughton WJ, Hernandez G, Blair MW, Beebe S, Gepts P, Vanderleyden J (2003) Bean (Phaseolus ssp.) - model food legumes. Plant Soil 252:55-128

Busogoro JP, Jijakli MH, Lepoivre P (1999) Identification of a novel source of resistance to angular leaf spot disease of common bean within the secondary gene pool. Plant Breed 118:417-423

Caixeta ZT, Borém A, Azevedo Fagundes S, Niestche S, Barros EG, Moreira MA (2003) Inheritance of angular leaf spot resistance in common bean line BAT 332 and identification of RAPD marker linked to the resistance gene. Euphytica 134:297-303

Chang S, Puryear J, Cairney J (1993) A simple and efficient method for isolating RNA from pine trees. Plant Mol Biol Rep 11:113-116

Chapman A, Blebacq AS, Vasseur J, Hilbert JL (2000) Arabinogalactanproteins in Cichorium somatic embryogenesis: effet of betaglucosyl Yariv reagent and epitope localization during embryo development. Planta 211:305-314

Cushing DA, Forsthoefel NR, Gestaut DR, Vernon DM (2005) Arabidopsis emb175 and other ppr knockout mutant reveal essential roles for pentatricopeptides repeat (PPR) proteins in plant embryogenesis. Planta 221:424-436

Diatchenko L, Chris Lau YF, Campbell AP, Chenchik A, Moqadam F, Huang B, Lukyanov S, Lukyanov K, Gurskaya N, Sverdlov ED, Siebert PD (1996) Suppression subtractive hybridization: a method for generating differentially regulated or tissue-specific cDNA probes and libraries. Proc Natl Acad Sci USA 93:6025-6030

Ding YH, Liu NY, Tang ZS, Liu J, Yang WC (2006) Arabidopsis GLUTAMINE-RICH PROTEIN23 is essential 
for early embryogenesis and encodes a novel nuclear PPR motif protein that interacts with RNA polymerase II subunit III. Plant Cell 18:815-830

Geerts P, Toussaint A, Mergeai G, Baudoin JP (2002) Study of the early abortion in reciprocal crosses between Phaseolus vulgaris L. and Phaseolus polyanthus Greenm. Biotechnol Agron Soc Environ 6:109-119

Geng YJ, Gao ST, Huang DN, Zhao YR, Liu JP, Li XH, Zhang RL (2009) Differentially expressed genes between female and male adult Anopheles anthropophagus. Parasitol Res 105:843851

Gutierrez-Marcos JF, Dal Pra M, Giulini A, Costa LM, Gavazzi G, Cordelier S, Sellam O, Tatout C, Paul W, Perez P, Dickinson H, Consonni G (2007) empty pericarp4 encodes a mitochondrialtargeted pentatricopeptide repeat protein necessary for seed development and plant growth in maize. Plant Cell 19:196-210

José-Estanyol M, Ruiz-Avila M, Puidomènech P (1992) A maize embryo-specific gene encodes a proline-riche and hydrophobic protein. Plant Cell 4:413-423

Kaplan DR, Cooke TJ (1997) Fundamental concepts in the embryogenesis of dicotyledons: a morphological interpretation of embryo mutant. Plant Cell 9:1903-1919

Konishi T, Sassaki Y (1994) Compartmentalization of two forms of acetyl-CoA carboxylase in plants and the origin of their tolerance toward herbicides. Proc Natl Acad Sci USA 91:3598-3601

Lara P, Onate-Sanchez L, Abraham Z, Ferrandiz C, Diaz I, Carbonero P, Vicente-Carbajosa J (2003) Synergetic activation of seed storage protein gene expression in Arabidopsis by ABI3 and two bZIPs related to OPAQUE2. J Biol Chem 23:21003-21011

Legrand S, Hendriks T, Hilbert J, Quillet M (2007) Characterization of expressed sequence tags obtained by SSH during somatic embryogenesis in Chichorium intybus L. BMC Plant Biol 7:27

Linkiewicz A, Filipecki M, Tomczak A, Grabowska A, Malepszy S (2004) The cloning of sequences differentially transcribed during the induction of somatic embryogenesis in cucumber (Cucumis sativus L.). Cell Mol Biol Lett 9:795-804

Lurin $\mathrm{C}$, Andrés $\mathrm{C}$, Aubourg S, Bellaoui $\mathrm{M}$, Bitton $\mathrm{F}$, Bruyère $\mathrm{C}$, Caboche M, Debast C, Gualberto J, Hoffmann B, Lecharny A, Ret ML, Martin-Magniette ML, Mireau H, Peeters N, Renou JP, Szurek B, Taconnat L, Small I (2004) Genomewide analysis of Arabidopsis pentatricopeptide repeat (PPR) proteins reveals their essential role in organelle biogenesis. Plant Cell 16:2089-2103

Mahuku GS, Jara CE, Cajiao C, Beebe S (2002) Sources of resistance to Colletotrichum lindemuthianum in the secondary gene pool of Phaseolus vulgaris and in crosses of primary and secondary gene pools. Plant Dis 86:1383-1387

Marenda MS, Vilei EM, Poumarat F, Frey J, Berthelot X (2004) Validation of the suppressive subtractive hybridization method in Mycoplasma agalactiae species by the comparison of a field strain with the type strain PG2. Vert Res 35:199-212

Miller NA, Gong Q, Bryan R, Ruvolvo M, Turner LA, LaBrie ST (2002) Cross-hybridization of closely related genes on highdensity macroarrays. Biotechniques 32:620-625

Müller M, Knudsen S (1993) The nitrogen response of a barely C-hordein promoter is controlled by positive and negative regulation of the GCN4 and endosperm box. Plant J 4:343-355

Namasivayam P, Hanke D (2006) Identification of differentially expressed sequences in pre-embryonic tissue of oilseed rape by suppression subtractive hybridization (SSH). Plant Cell Tiss Organ Cult 86:417-421

Nguema Ndoutoumou P, Toussaint A, Baudoin JP (2007) Embryo abortion and histological features in the interspecific cross between Phaseolus vulgaris L. and Phaseolus coccineus L. Plant Cell Tissue Organ Cult 88:329-332
Prabu G, Kawar PG, Pagariya MC, Prasad DT (2011) Identification of water deficit stress upregulated genes in sugarcane. Plant Mol Biol Rep 29:291-304

Rainey KM, Griffiths PD (2005) Inheritance of heat tolerance during reproductive development in snap bean (Phaseolus vulgaris L.). J Am Soc Hortic Sci 130:700-706

Rozen S, Skaletsky HJ (2000) Primer3 on the WWW for general users and for biologist programmers. In: Krawetz S, Misener S (eds) Bioinformatics methods and protocols: methods in molecular biology. Humana Press, Totowa, NJ, pp 365-386

Saha D, Prasad AM, Srinivasan R (2007) Pentatricopeptide repeat proteins and their emerging roles in plants. Plant Physiol Biochem 45:521-534

Schaller A (2004) A cut above the rest: the regulatory function of plant proteases. Planta 220:183-197

Schmidt RJ, Ketudat M, Aukerman MJ, Hoschek G (1992) Opaque-2 is a transcriptional activator that recognizes a specific target site in 22-kD zein genes. Plant Cell 4:689-700

Schmit V, Baudoin JP (1992) Screening for resistance to Ascochyta blight in populations of $P$. coccineus $\mathrm{L}$. and $P$. polyanthus Greenman. Field Crops Res 30:155-165

Schmitz-linneweber C, Small I (2008) Pentatricopeptide repeat proteins: a socket set for organelle gene expression. Trends Plant Sci 13:663-670

Schmitz-linneweber C, Williams-Carrier R, Barkan A (2005) RNA immunoprecipitation and microarray analysis show a chloroplast pentatricopeptide repeat protein to be associated with the $5^{\prime}$ region of mRNAs whose translation it activates. Plant Cell 17:2791-2804

Showalter AM (2001) Arabinogalactan-proteins: structure, expression and function. Cell Mol Life Sci 58:1399-1417

Suda CNK, Giorgini JF (2003) Multiple forms of endo-1,4- $\beta-1,3-$ glucanases in the endosperm of Euphorbia heterophylla L. J Exp Bot 54:2045-2052

Sun MM, Li LH, Xie H, Ma RC, He YK (2007) Differentially expressed genes under cold acclimatation in Physcomitrella patens. J Biochem Mol Biol 40:986-1001

Toussaint A, Geerts P, Clement F, Mergeai G, Baudoin JP (2004) Early abortion in reciprocal crosses between Phaseolus vulgaris and Phaseolus polyanthus, and in vitro culture of immature embryos from these species. Belgium J Botany 137:47-54

Tsuwamoto R, Fukuoka H, Takahata Y (2007) Identification and characterization of gene expressed in early embryogenesis from microspores of Brassica napus. Planta 225:641-652

Tzafrir I, Pena-Muralla R, Dickerman A, Berg M, Rogers R, Hutchens S, Sweeney TC, McElver J, Aux G, Patton D, Meinke DW (2004) Identification of genes required for embryo development in Arabidopsis. Plant Physiol 135:1206-1220

Von Stein OD, Thies WG, Hofmann M (1997) A high throughput screening for rarely transcribed differentially expressed genes. Nucleic Acids Res 25:2598-2603

Wang G, Gao Y, Yang L, Shi J (2007) Identification and analysis of differentially expressed genes in differentiating xylem of Chinese fir (Cunninghamia lanceolata) by suppression subtractive hybridization. Genome 50:1141-1155

Williamson MP (1994) The structure and function of proline-rich regions in proteins. Biochem J 297:249-260

Yang G, Zhou R, Tang T, Chen X, Ouyang J, He L, Li W, Chen S, Guo M, Li X, Zhang C, Shi S (2011a) Gene expression profiles in response to salt stress in Hibiscus tiliacens. Plant Mol Biol Rep 29:609-617

Yang Z, Peng Z, Yang H, Yang J, Wei S, Cai P (2011b) Suppression subtractive hybridization identified differentially expressed genes in pistil mutations in wheat. Plant Mol Biol Rep 29:431-439

Zhou MB, Yang P, Gao PJ, Tang D (2011) Identification of differentially expressed sequence taqs in rapidly elongating Phyllostachys pubescens internodes by suppressive subtractive hybridization. Plant Mol Biol Rep 29:224-231 